\title{
街路樹のある街路空間における現地・スライド評価実験 による心理評価の比較研究
}

A Comparative Study of Psychology Evaluation by On-site and Using Slide Evaluation Methods in Street Space with Roadside Trees

遠藤 裕志* 山田 宏之**

Hiroshi ENDO Hiroyuki YAMADA

Abstract : Inthis research, evaluation experiment of Semantic Differential method was conducted by on-site and using slide aimed to verify the validity of the using slide evaluation method when evaluating psychological effect by roadside trees. From the result of factor analysis of each evaluation experiment result, psychological, view, spatial evaluation factor was extracted, and evaluation structure of roadside trees was no big difference in each methods. Moreover, from the result of cluster analysis by using factor score of psychological and view evaluation factor, the evaluation result of each methods was brought together in the same cluster on most streets, and it was suggested that validity of using slide evaluation method is high. But the difference in each methods was seen on a part of street. Because it was not possible to evaluate accurately from the slide that existence of living things and street information on pavement width and tree height.

Keywords: Roadside trees, Psychology evaluation, Factor analysis, Using slide evaluation, On-site evaluation, Cluster analysis キーワード：街路樹, 心理評価, 因子分析, スライド評価, 現地評価, クラスター分析

\section{1. 緒論}

これまで，建設省（現国土交通省）は都市内部の緑の量的充実 により国民の身近な緑に対するニーズに応えようとしてきたが, 今後は緑化の質の向上により応えていくことが必要とされている。 現在, ストレスの多い都市環境で生活する人々にとって, 身近な 緑の果たす心理的効果が期待されており, 都市内部において最む 身近な緑の 1 つである街路樹についてもこの効果は注目されてい る。そのため, 街路樹が果たす心理的効果の評価・検証研究がい 〈つ屯行われている1 ${ }^{1)}$ 2)。しかし, これらのほとんどの研究は, 対象街路をスライドや CG を用いた画像などの静止画で表現して いる。ここで, 心理的効果は「アメニティ（快適性）が高まる効 果」と定義され ${ }^{3}$, アメニティのように本来五感を使って感じと るものを，スライドのように得られる情報が視覚情報に限られる 表現手法から感じとることは困難であり，正確にアメニティ評価, つまり，心理的効果の評価が出来ない可能性があると考えられる。 また，既往研究においても，スライドを用いた評価手法と結果の

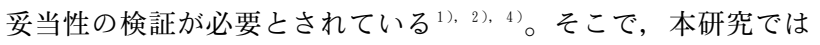
スライド評価と現地評価を行い, 心理的効果の評価に差（以下 手法差）があるか否かを検証することを目的とした。

\section{2. 研究方法}

(1) 本研究の流れ

本研究は, 既往研究と同様に言語尺度 (以下 評価項目) を用 いた SD 法による評価方法で行うこととし，SD 法の手順を参考 に本研究の計画を立てた。本研究のフローチャートを図ー 1 に示す。 (2) 調査対象及び評価実験日時

本研究では, 評価手法以外の条件の違いが, 研究結果に影響を 与えないよう考慮した結果, 被験者には和歌山大学を主とした大 学生 40 名 (男性 26 名, 女性 14 名), 調査対象地には和歌山大学 から程近い和歌山市内の街路空間のうち, 植栽樹種や樹種構成, 配植等が多様となるように, 8 街路（1 中央通り，2 屋形通り，3

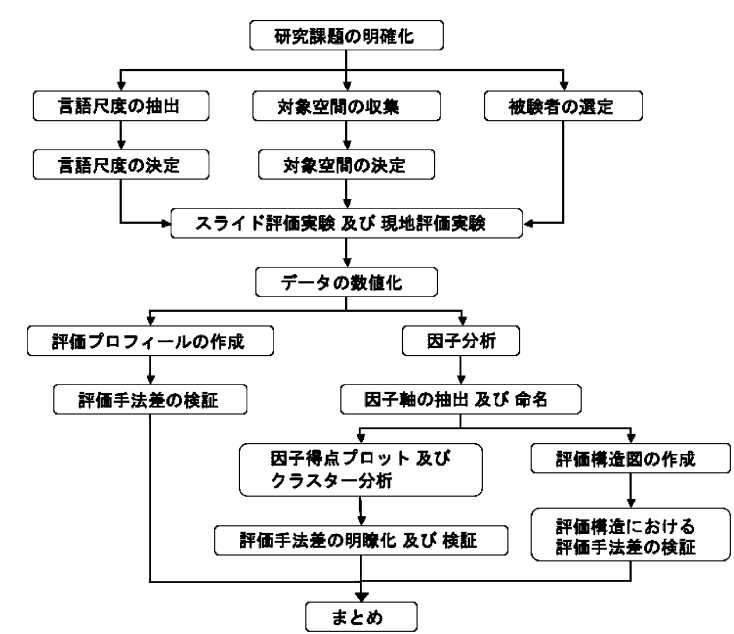

図ー 1 本研究のフローチャート

表 -1 調査対象街路情報

\begin{tabular}{|c|c|c|c|c|c|c|c|}
\hline №. & 調查対象街路客 & 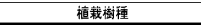 & 慗高 $(\mathrm{m})$ & 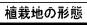 & 画植 & 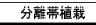 & 歩道幅員 (m) \\
\hline 1 & 中央通り & フウ & 6.5 & 植樹带 & 不等間閶 & 無 & 4.3 \\
\hline 2 & 星形通川 & イチョウノモミジハススカケノき & 6.5 & 䐈樯柣 & 不等間隔 & 有 (クスノキ) & 5.0 \\
\hline 3 & 楖通り & シダレヤナギ & 6.5 & 植樹带 & 不等間限 & 無 & 6.0 \\
\hline 4 & 三年坂通り & イチョウ & 8.0 & 植㭙带 & 不等間网 & 無 & 3.4 \\
\hline 5 & 塩屋街道 & イチョウ & 5.5 & 㥀榬树 & 等間隔 & 有(クスノキ) & 1.5 \\
\hline 6 & 策地通り & トチノキ & 6.5 & 植格栟 & 不等間网网 & 有 $(ケ ヤ キ)$ & 3.4 \\
\hline 7 & 大新通り & イチョウ & 7.0 & 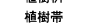 & 等間隔 & 無 & 2.3 \\
\hline 8 & ケヤキ大通り & イチョウ & 8.0 & 植㭙带 & 不等間凪成 & 有(活ヤキ) & 3.7 \\
\hline
\end{tabular}

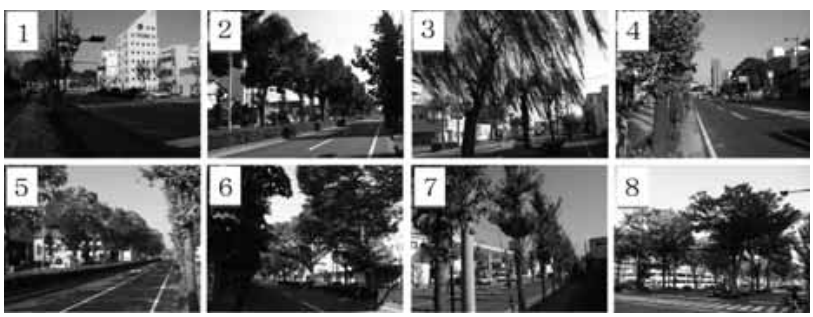

写真－1 各街路写真（写真内番号は調査対象街路 No.）

*和歌山大学大学院システム工学研究科 **和歌山大学システム工学部 

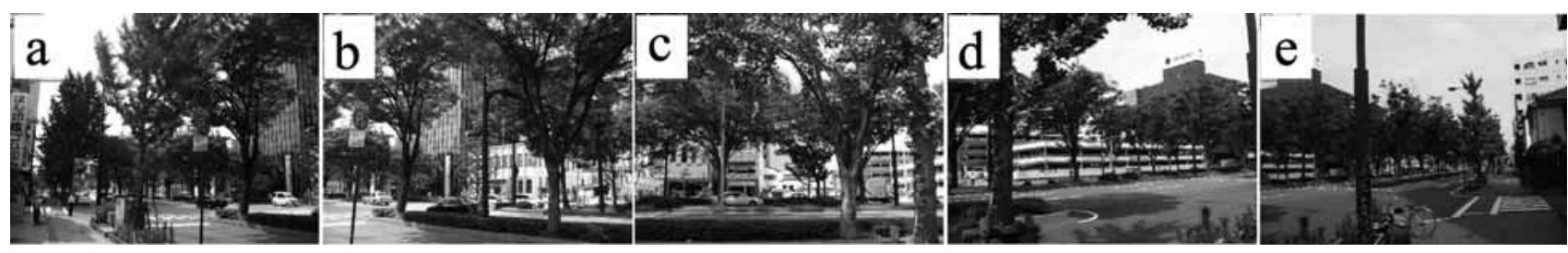

写真－２スライド写真（８ケヤキ大通り）

\begin{tabular}{|c|c|c|}
\hline 評価実験 & 日時 & 被験者 \\
\hline 夏季評価実験 & 2006年8月 22 日及び23日 10 時-14時 & 24名（男性13名·女性11名) \\
\hline 秋季評価実験 & 2006年10月24日１0時-14時 & 18名（男性12名·女性6名） \\
\hline 冬季評価実験 & 2006年12月21日及び22日 & 18名（男性11名·女性7名） \\
\hline
\end{tabular}

柳通り, 4 三年坂通り, 5 塩屋街道, 6 築地通り, 7 大新通り, 8 ケヤキ大通り）を選定した。調査対象街路情報を表- 1 に, 各街 路の代表的な写真を写真一 1 に示す。また, 各季節に行なった評 価実験の日時や被験者の情報を表一 2 に示す。

\section{(3) 評価項目の抽出}

$\mathrm{SD}$ 法に用いる評価項目を決定するため, 既往研究 ${ }^{11,5)}$ からの 抽出及び評価項目抽出アンケート調査を行なった。評価項目抽出 アンケート調査は, 街路樹のある街路空間を評価する際に既往研 究で用いられている評価項目だけで十分か否か確認することを目 的として行なった。調查期間は, 2006 年 6 月 6 日から 6 月 22 日 までとし, 和歌山大学の学生及び教職員 102 名（男性 70 名, 女 性 32 名）を対象に行なった。日本各地の街路樹のある街路空間 の写真を被験者に提示し, 感じた事を自由に書いてもらう自由記 述式のアンケートとした。以上の結果から, 本研究で初めて用い る評価項目を含む 30 対を抽出した。

\section{（4）評価実験方法}

スライド評価実験は, 和歌山大学総合研究棟 S401 教室にて行 なった。各街路において街路樹を含む車道側が $180^{\circ}$ 見渡せるよ う撮影した 5 枚の写真を, 240 秒間プロジェクターによりスクリー ンへ投影し, 同時に 30 対の評価項目を 7 段階で評価する方法之 した。スライド評価実験に用いた 5 枚の写真の一部を写真 -2 に示す。現地評価実験は, スライド評価実験終了後に被験者を現 地に連れて行き，スライド撮影地周辺を 240 秒間自由に散策して
もらうと同時に 30 対の評価項目を 7 段階で評価する方法とした。 この際, 街路及び評価項目の順序は手法により異なるよう留意し た。

\section{(5) 解析方法}

各季節別に行なった，SD 法による各手法の評価実験結果から， 評価項目ごとの評価得点の平均值をそれぞれ算出し, 街路空間別 に手法差があるか否かを検証するために評価プロフィールを作成 した。また, 街路樹のある街路空間を評価する際の被験者の評価 構造・視点を把握するために因子分析を行なった。因子分析は, 固有值 1 以上の基準を設けて因子数を決定し, 各因子の因子負荷 量の上位の評価項目を参考に因子名を決定した。さらに，因子分 析によって得られた各因子の因子得点を用いて，2 次元座標平面 上にプロットし，クラスター分析（最長距離法）を行ない，互い の距離が 2.0 以下ならばまとめるという基準で, 評価の類似して いる結果をグルーピングした。

\section{3. 結果及び考察}

\section{(1) 因子分析}

各季節・各手法で行なった全評価実験の総合結果と, 各手法で の結果に対して，それぞれ因子分析を行なった。その結果，総合 結果については累積寄与率 $83.1 \%$ で 3 因子にまとめられ， スラ イド評価の結果については累積寄与率 $85.8 \%$ で 3 因子に（表一 3 ), 現地評価の結果については累積寄与率 $85.8 \%$ で 4 因子にま とめられた（表一 4 ）。全ての因子分析結果について, 第 1 因子, 第 2 因子, 第 3 因子までは含まれる評価項目が酷似しており, 順 に心理的評価因子, 眺望的評価因子, 空間的評価因子とした。つ まり，これらが街路樹のある街路空間を評価する際の被験者の評 価構造・視点を形成しており，各手法で大きな手法差は見られな
表－3 因子分析結果（スライド評価 ）

\begin{tabular}{|c|c|c|c|}
\hline \multicolumn{4}{|c|}{ 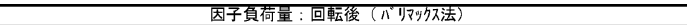 } \\
\hline 評価項目 & 心理的評価因子 & 眺望的評価因子 & 空間的評価因子 \\
\hline 気持ち良い一良くない & 0.897 & -0.370 & 0.181 \\
\hline 美しい一美しくない & 0.894 & -0.297 & 0.180 \\
\hline 歩きたい一歩きたくない & 0.890 & -0.396 & 0.184 \\
\hline 好ましいー好ましくない & 0.889 & -0.345 & 0.273 \\
\hline 快適な一不快な & 0.889 & -0.262 & 0.305 \\
\hline やすらぐーやすらがない & 0.877 & -0.419 & 0.181 \\
\hline 安心できる一不安な & 0.877 & -0.254 & 0.283 \\
\hline 親しみのある一ない & 0.873 & -0.176 & 0.328 \\
\hline 魅力的な一つまらない & 0.851 & -0.428 & 0.238 \\
\hline 休みたい一休みたくない & 0.836 & -0.473 & 0.201 \\
\hline さわやかなーうっとうしい & 0.828 & 0.015 & 0.368 \\
\hline 奥行きのある一ない & 0.792 & -0.340 & 0.378 \\
\hline 変化のある一単調な & 0.788 & -0.382 & -0.167 \\
\hline 自然的な一人工的な & 0.782 & -0.410 & 0.215 \\
\hline 力強い一弱々しい & 0.745 & -0.515 & 0.340 \\
\hline 涼しそうな一暑そうな & 0.723 & -0.419 & 0.043 \\
\hline 䦌いのあるーない & 0.713 & -0.636 & 0.215 \\
\hline 車道と分離された一分離されていない & 0.693 & 0.008 & -0.073 \\
\hline 鳥がいそうなーいなさそうな & 0.689 & -0.570 & 0.362 \\
\hline 緑が豊かな一乏しい & 0.676 & -0.639 & 0.214 \\
\hline 虫がいそうなーいなさそうな & 0.644 & -0.594 & 0.321 \\
\hline 印象的な一印象の薄い & 0.557 & -0.459 & 0.184 \\
\hline 季節感のある一ない & 0.448 & -0.175 & 0.428 \\
\hline 開放感のある一圧迫感のある & -0.275 & 0.916 & -0.029 \\
\hline 見睛らしの良いー良くない & -0.438 & 0.875 & -0.075 \\
\hline 広々とした一狭苦しい & 0.091 & 0.873 & -0.023 \\
\hline すっきりしたーごみごみした & -0.509 & 0.842 & -0.099 \\
\hline 明るい一暗い & -0.232 & 0.726 & 0.048 \\
\hline 統一感のある一ない & 0.041 & -0.050 & 0.994 \\
\hline まとまりのあるーない & 0.419 & 0.041 & 0.860 \\
\hline 因子名 & 心理的評価因子 & 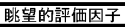 & 空間的評価因子 \\
\hline 二乗和 & 14.9 & 7.46 & 3.35 \\
\hline 寄与率 & $49.8 \%$ & $24.9 \%$ & $11.2 \%$ \\
\hline 累㺓寄与率 & $49.8 \%$ & $74.6 \%$ & \\
\hline
\end{tabular}

表－4 因子分析結果（現地評価）

\begin{tabular}{|c|c|c|c|c|}
\hline \multicolumn{5}{|c|}{ 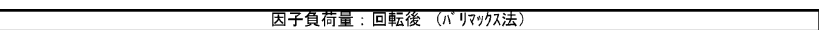 } \\
\hline 評価項目 & 心理的評価因子 & 鮡望的評価因子 & 空間的諯価因子 & 明瞭的評価因子 \\
\hline 好ましいー好ましくない & 0.945 & 0.032 & 0.175 & -0.202 \\
\hline 鳥がいそうな一いなさそうな & 0.931 & -0.063 & 0.129 & 0.035 \\
\hline 変化のある一単調な & 0.921 & 0.004 & -0.198 & -0.105 \\
\hline 親しみのあるーない & 0.921 & 0.022 & 0.261 & -0.095 \\
\hline 気持ち良い一良くない & 0.919 & 0.001 & 0.053 & -0.253 \\
\hline 潤いのあるーない & 0.909 & -0.184 & 0.091 & -0.249 \\
\hline 魅力的な一つまらない & 0.909 & 0.083 & 0.230 & -0.227 \\
\hline 自然的な一人工的な & 0.906 & -0.089 & 0.035 & -0.176 \\
\hline 力強い一弱々しい & 0.898 & 0.024 & 0.303 & -0.012 \\
\hline 美しい一美しくない & 0.897 & 0.076 & 0.227 & -0.148 \\
\hline 快適な一不快な & 0.891 & 0.087 & 0.231 & -0.269 \\
\hline 緑が豊かな一乏しい & 0.890 & -0.286 & 0.008 & -0.186 \\
\hline 安心できるー不安な & 0.879 & 0.162 & 0.279 & -0.152 \\
\hline 歩きたいー歩きたくない & 0.876 & 0.141 & 0.233 & -0.339 \\
\hline さわやかなーうつとうしい & 0.871 & 0.126 & 0.117 & -0.158 \\
\hline 休みたい一休みたくない & 0.870 & 0.160 & 0.171 & -0.364 \\
\hline 虫がいそうな一いなさそうな & 0.867 & -0.201 & 0.158 & -0.226 \\
\hline やすらぐーやすらがない & 0.855 & 0.097 & 0.225 & -0.337 \\
\hline 奥行きのある一ない & 0.765 & 0.181 & 0.289 & -0.289 \\
\hline 凉しそうな一暑そうな & 0.615 & 0.027 & 0.141 & -0.710 \\
\hline 道と分離された一分離されていない & 0.559 & 0.494 & 0.002 & -0.017 \\
\hline 開放感のある一圧迫感のある & $\overline{0.012}$ & 0.913 & -0.083 & 0.048 \\
\hline 広々とした一狭苦しい & 0.388 & 0.856 & -0.235 & -0.095 \\
\hline 見睛らしの良い一良くない & -0.191 & 0.811 & -0.147 & 0.230 \\
\hline まとまりのあるーない & 0.367 & -0.173 & 0.904 & 0.010 \\
\hline 統一感のある一ない & 0.025 & -0.230 & 0.867 & -0.190 \\
\hline 季節感のある一ない & 0.352 & -0.044 & 0.406 & -0.076 \\
\hline 明るいー暗い & -0.099 & 0.453 & -0.117 & 0.718 \\
\hline 印象的な一印象の薄い & 0.578 & 0.011 & 0.374 & -0.627 \\
\hline すっきりしたーごみごみした & -0.519 & 0.533 & 0.177 & 0.541 \\
\hline 因子名 & 心理的評価因子 & 眺望的評価因子 & 空間的評価因子 & 明瞭的評価因子 \\
\hline 二㮔和 & 16.8 & 3.36 & 2.77 & 2.76 \\
\hline 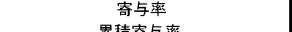 & $56.2 \%$ & $11.2 \%$ & $9.24 \%$ & $9.18 \%$ \\
\hline 累樍寄与率 & $56.2 \%$ & $67.4 \%$ & $76.6 \%$ & $85.8 \%$ \\
\hline
\end{tabular}


かった。

ここで，心理的評価因子に含まれる評価項目に注目してみると， 「気持ち良い」「好ましい」「快適な」などの既往研究で心理評価の 指標として用いられていた評価項目と，「歩きたい」「休みたい」 「鳥がいそうな」「虫がいそうな」などの本研究で初めて用いた, 生理的欲求を問う評価項目や生物の存在を感じるか否かを問う評 価項目も高い因子負荷量で一緒にまとめられたことから，これら の評価項目も心理評価に大きく影響を与えている可能性が考えら れる。

\section{（2）因子得点プロット及びクラスター分析}

さらに, 総合結果の因子分析結果の第 1 因子と第 2 因子の因子 得点を用いて, 各季節 2 次元座標平面上にプロットし, クラスター 分析を行ない，手法差の検証を行なった。以下の各図は，左にい くほど第 1 因子の評価が高く, 下に行くほど第 2 因子の評価は高 ( ${ }^{6)}$ 。また，各プロットは「季節一調査対象街路 No. 一評価手法」 で表記しており, 季節は $\mathrm{S}$ 夏季, $\mathrm{F}$ 秋季, $\mathrm{W}$ 冬季とし, 評価手 法は $\mathrm{S}$ スライド評価, G 現地評価である。

夏季の評価実験の結果を図－2 に示す。 8 つの街路における各 手法の結果は, 4 つのクラスターに分類でき, 各手法で異なるク ラスターに属した街路は, 2 屋形通り, 5 塩屋街道, 6 築地通り であった。このうち, 2 屋形通り, 6 築地通りについては, 心理 的評価因子より眺望的評価因子に起因する手法差と考えられ, 現 地評価の方が評価は高いことから，開放感や見晴らしなど，スラ イド評価では街路を空間的に捉えることが難しいと考えられる。 心理的評価因子に起因する手法差についてみると, 5 塩屋街道や 1 中央通りでは大きく, また 5 塩屋街道と 7 大新通りのみ, 他街 路とは異なりスライド評価の方が評価は高い結果となった。

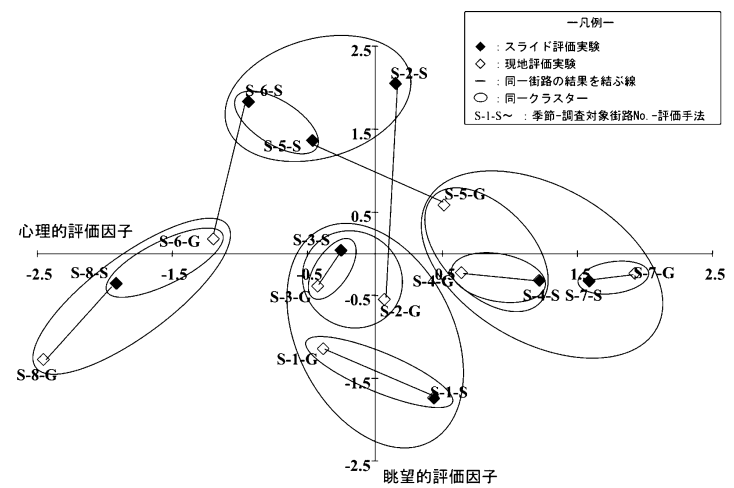

\section{図－２＼cjkstart第 1 因子×第 2 因子 因子得点プロット図 夏季}

秋季の評価実験の結果を図 -3 に示す。秋季の結果についても 夏季の結果之同様に，4つのクラスターに分類でき，そのうち， 8 ケヤキ大通りの現地評価は単独で 1 つのクラスターを形成して いる。各手法で異なるクラスターに属した街路は, 2 屋形通り, 4 三年坂通り, 5 塩屋街道, 8 ケヤキ大通りであった。秋季の結 果についても, 2 屋形通り, 8 ケヤキ大通りは眺望的評価因子に 起因する手法差と考えられる。 4 三年坂通りと 5 塩屋街道は心理 的評価因子に起因する手法差がみられ, 夏季と同様に 5 塩屋街道 と 7 大新通りのみ, 他街路とは異なりスライド評価の方が評価は 高い結果となった。

冬季の評価実験の結果を図 -4 に示す。冬季の各手法の結果は, 5 つのクラスターに分類でき, 7 大新通りの各手法の結果で 1 つ のクラスターを形成している。冬季の結果は他季節の結果と比較 してばらつきが小さく, 各手法で異なるクラスターに属した街路 は，3柳通り，6 築地通りのみであった。

各季節に行なった評価実験の結果から, 本研究で調査対象地と して選定した街路は，心理的評価因子の評価の高い街路から，8 ケヤキ大通り, 6 築地通り, 3 柳通り, 2 屋形通り, 5 塩屋街道,

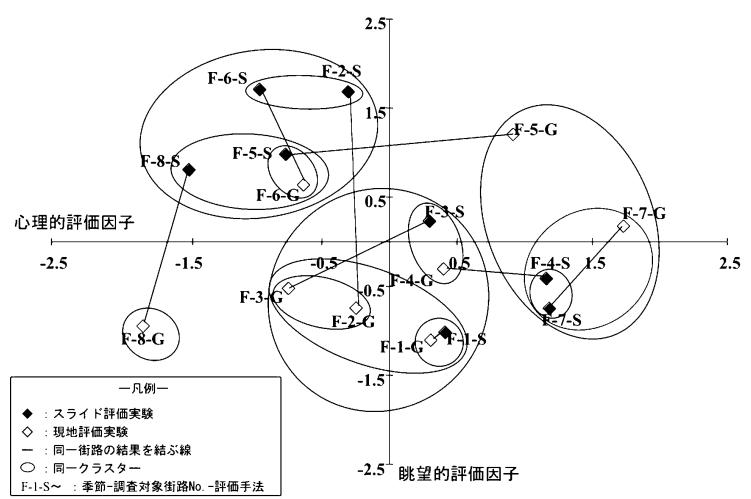

図-3 第 1 因子 $\times$ 第 2 因子 因子得点プロット図 秋季

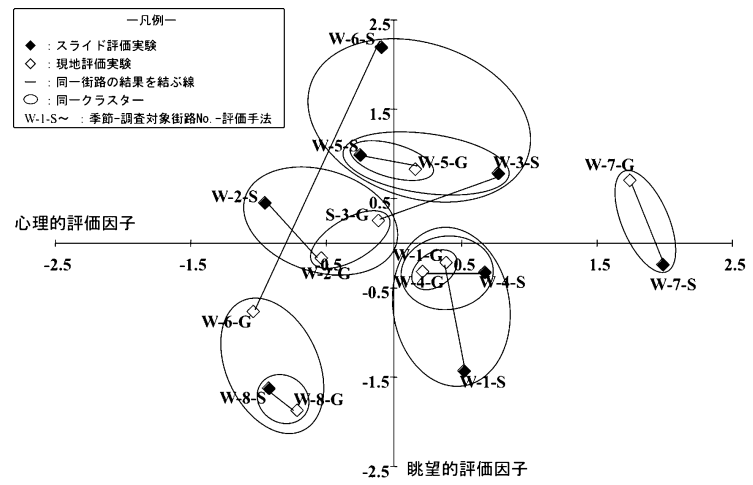

図-4 第 1 因子×第 2 因子 因子得点プロット図 冬季

1 中央通り, 4 三年坂通り, 7 大新通りという順であった。この 結果は, 各街路の緑量の順之一致しており, また, この結果は夏 季と秋季については共通しており，冬季のみ多少順番が異なる結 果となったことから, 心理評価と緑量の間には相関がある可能性 が考えられる。ここで, 緑化された屋上の景観要素の違いと屋上

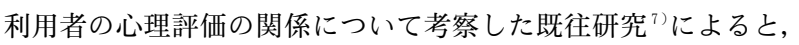
屋上の緑視率と心理評価には高い相関があり, 緑視率が高い程心 理評価も高いという結果が出ている。本研究では緑量と心理評価 の関係については，目的が異なるため詳しく検証していないが， 緑量と心理評価に相関があるとすれば，街路樹の緑量が十分にス ライドから伝わるようなスライドの撮影法・表現法にする必要が ある。

各季節の因子得点プロット図の結果から分かるように，いくつ かの街路で手法によってクラスターが異なる結果となったが，そ の要因としては, 心理的評価因子ではなく眺望的評価因子が影響 していると考えられる。つまり，スライドを用いた心理評価の妥 当性は高いと考えられる。

各季節, 各街路の心理評価の手法別結果に着目してみると, ほ とんどの街路で同一クラスター内に収まってはいるが, 現地評価 の方が心理評価は高い傾向を示した。つまり，スライドを用いた 景観・心理評価を行なっている既往研究の結果についても, 実際 に現地での評価より過小評価となっていた可能性も考えられる。 しかし, 一部の街路, 5 塩屋街道, 7 大新通りでは夏季秋季とス ライド評価の方が高い結果が得られ，冬季については 5 塩屋街道 のみスライド評価の方が評価は高いという結果が得られた。これ ら両街路は, 共に強剪定された樹高 $5.5 \mathrm{~m}$ 以上のイチョウが植え られており, 歩道幅員がそれぞれ $1.5 \mathrm{~m}, 2.3 \mathrm{~m}$ と他の街路と比較 して狭い街路であった。景観上好ましい街路樹の樹高と歩道幅員 の関係について考察した既往研究 ${ }^{11}$ の結果から, これらの街路条 件は景観上好ましいとは言えず，これらの街路情報がスライドか らは正確に得ることが出来ず, 現地では評価がスライドより低く 
なるという結果が出たのではない かと考えられる。つまり, 現地の 再現性という観点からすると, 植 栽樹種の樹高や歩道幅員が分かり やすいスライドを撮影し, 調査に 用いることで，スライド評価手法 の精度がより高くなると考えられ る。

\section{（3）評価プロフィール}

各季節, 街路空間別の評価プロ フィールを作成し，手法差がある か否かの検証を行なった。夏季の 評価実験の街路空間別の評価プロ フィールを図ー 5 に示す。

図ー 5 の評価プロフィールに用 いた手法差別の因子得点の差を $\mathrm{t}$ 検定した結果， $1 \%$ 水準で有意な 差が認められた項目は, 最も少な い街路で 1 項目, 最も多い街路で 10 項目であったが, 差の絶対值 についてみると, 大部分が 1.0 以 下と小さかった。その中でも夏季 の因子得点プロット及びクラスター分析の結果において, 手法に よって異なるクラスターに属した， 2 屋形通り，6 築地通りにつ いて注目してみると, 両街路に共通して評価項目「明るい」「すっ きりした」では大きな手法差が見られた。これらの評価項目は, 総合結果の因子分析結果では共に眺望的評価因子に含まれており, これらの評価項目での手法差が, 因子得点プロット及びクラスター 分析結果の手法差に影響を与えていると考えられる。また， 5 塩 屋街道と 7 大新通りについても, ほとんどの評価項目で, 各手法, 評価はほぼ一致していたが,「虫がいそうな」「休みたい」で共通 してスライドの方が評価は高いという手法差がみられ，5 塩屋街 道では「鳥がいそうな」「歩きたい」など, 生物の存在を感じる か否かを問う評価項目や生理的欲求を問う評価項目でも同様の手 法差がみられた。このことから, 因子得点プロット及びクラスター 分析結果における心理的評価因子の手法差に, これらの評価項目 が影響を与えている可能性も考えられる。また, 以上の結果から 心理評価の手法差を検証する際に, 既往研究のように因子得点を 用いて評価・検証しなくとも, 心理的評価因子に含まれる評価項 目の評価得点による評価・検証の有用性が高いと考えられる。

\section{4. 結論}

\section{（1）本研究におけるスライド評価の妥当性}

本研究は, 街路樹が果たす心理的効果を評価・検証する際に, スライドなど静止画で表現された街路樹から心理的効果を正確に 評価することが出来るのか，その手法と結果の妥当性を検証する ことを目的とし，スライド評価実験と現地評価実験を行なった。 その結果, 街路樹のある街路空間に対する被験者の評価構造・視 点は, 各手法で大きな手法差は見られなかった。また, 既往研究 と同様に, 心理的評価因子を用いて各街路で手法差について検証 した結果, ほとんどの街路で同一クラスターにまとめられ, 大き な手法差は見られなかった。いくつかの街路空間で手法によりク ラスターが異なる結果となったが，これらの街路空間の多くは， 心理的評価因子ではなく，「明るい」「すっきりした」などの眺望 的評価因子が手法差に起因していると考えられる。さらに, 各評 価項目の評価得点をまとめた評価プロフィールからも, ほとんよ゙ の評価項目で手法差は見られなかった。以上の結果から，スライ ドを用いた心理評価の妥当性は高いと考えられる。

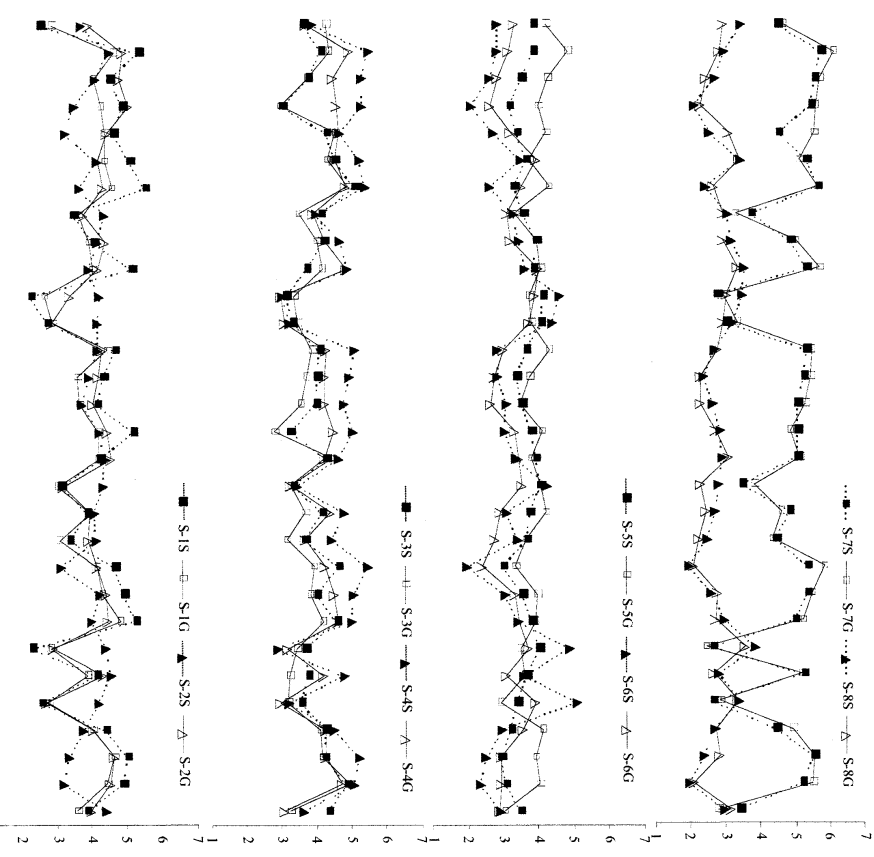

図－5 街路空間別評価プロフィール

しかし，5 塩屋街道のみ，季節を通じて心理評価に比較的大き な手法差が見られた。その要因としては，街路空間の特徴や評価 プロフィールの結果から, 街路情報（歩道幅員や樹高・樹形）が スライドからは十分に得ることが出来ない, 生物の存在を感じる か否かがスライドでは正確に評価出来ないことが挙げられる。

街路樹を含む都市の緑による心理評価や景観評価を行なう際は, 現地の環境が一定でないことや，被験者を現地に何箇所も連れて 行くことが困難であることから，スライドを用いて対象を表現す る方法が最善と考えられる。本研究の結果から, 現地の詳細な情 報，例えば樹高や歩道幅員，緑量などが十分に読み取れるような スライドを用いれば，高い精度で現地で行なうのと変わりない評 価が出来ると考えられる。

\section{(2) 今後の課題}

本研究は調查対象地が和歌山市内の 8 街路, 被験者が大学生と いう, 非常に限られた条件下で行われたものである。今後, 結果 をより汎用的なものにするためには，年齢や性別等の被験者属性 や, 植栽樹種や交通量等の街路情報についても多様にし, 検証を 重ねることが必要であると考えられる。また，本研究において， 生物の存在を感じるか否かを問う評価項目が心理的効果を左右す る要因の 1 つとして考えられたため, 評価項目についても今後さ らに検討する必要がある。

\section{補注及び引用文献}

1 ）亀野辰三ほか（2002）：歩行者から見た歩道植栽の景観イメー ジの評価：環境情報科学論文集 16,311-316

2 ) 市橋秀樹ほか (2000) : 街路植栽が歩行者及び運転者心理に及 ぼす影響 : ランドスケープ研究 63(5), 795-798

3 ) 国土交通省（2005）：都市の緑量と心理的効果の相関関係の社 会実験調查について

4) 亀野辰三ほか（2001）：運転者から見た分離帯高木植栽の景観 イメージの評価：ランドスケープ研究 64(5), 783-786

5 ）山下秋朝ほか（2001）：街路景観における街路樹の構成と心理 評価に関する研究：日本建築学会大会学術講演梗概集, 969-970

6 ) 形容詞対のうち, ネガティブな方向に高い得点を設けたため, 一般的な解釈と因子得点の正負が逆転している。

7 ) 佐々木ゆきほか（2004）：緑化された屋上における景観要素の 違いが利用者の景観評価に及ぼす影響：日本緑化工学会誌 30(1), 157-162 